\title{
A DISCUSSION OF THE RECENT RULING OF THE SOUTH AFRICAN SUPREME COURT OF APPEAL IN AFRIBUSINESS NPC V MINISTER OF FINANCE
}

\section{Peter Volmink and Allison Anthony}

\section{(2021) 8 APPLJ 1}

\begin{abstract}
The recent ruling by the South African Supreme Court of Appeal (SCA) in Afribusiness NPC v Minister of Finance raises questions about the lawfulness and fairness of the use of prequalification criteria in public procurement. In this case note we argue that the legality of regulation 4 of the Preferential Procurement Policy Framework Act of 2000 (PPPFA) and the principle of using prequalification criteria in public procurement are discrete issues. The SCA's finding on the legality issue - that regulation 4 is ultra vires the PPPFA - is unsurprising. Indeed, it is difficult to reconcile the use of prequalification criteria for "designated groups" as set out in reg 4 with the preference-point system prescribed by the PPPFA. However, we question the correctness of the court's view that prequalification criteria do not satisfy the objectives of section 217(1) of the Constitution, such as fairness, transparency etc. In our view, there is nothing constitutionally suspect about the use of prequalification criteria as a tool to promote socio-economic objectives, provided they are designed and implemented within the discipline required by the Constitution. Properly-designed prequalification criteria serve as important tools for the protection and advancement of persons disadvantaged by unfair discrimination, as envisaged in section $217(2)(b)$. Furthermore, we recommend that the drafters of the regulations take the opportunity created by the SCA's ruling to revise the regulations as a whole. In our view, the problems with the regulations are not confined to the impugned regulations $3(b), 4$ and 9 , but extend to other regulations as well - most notably, regulations 5 and 6 dealing with the preference point system and regulation 8 dealing with local content and production. We argue that these regulations do not award preference points for "specific goals" in the manner contemplated by the PPPFA, and are thus susceptible to challenge. Ultimately, the problems with the regulations are traceable to design defects in the PPPFA itself. The PPPFA cannot be "fixed". It has run its course and must be replaced with a new legislative framework as a matter of urgency.
\end{abstract}




\section{A DISCUSSION OF THE RECENT RULING OF THE SOUTH AFRICAN SUPREME COURT OF APPEAL IN AFRIBUSINESS NPC V MINISTER OF FINANCE}

Peter Volmink

BA (law) LLB, LLM, PhD

Member of the Johannesburg Bar

Research Fellow, Department of Mercantile Law, Stellenbosch University

Allison Anthony

BA (law), LLB, LLM, LLD

Senior Lecturer, Department of Public, Constitutional and International Law, School of Law, UNISA

Deputy Director, African Procurement Law Unit

\section{Introduction}

Recently, in Afribusiness NPC v Minister of Finance, ${ }^{1}$ the Supreme Court of Appeal (SCA) declared that the Preferential Procurement Regulations, 2017 were inconsistent with the Preferential Procurement Policy Framework Act 5 of 2000 (PPPFA or the Act), and ruled that the regulations were invalid. The court exercised its powers in terms of section 172(1)(b)(ii) of the Constitution of the Republic of South Africa, 1996 and suspended the order of invalidity for a period of 12 months to allow the Minister to correct the defects. The main finding was that the regulations were ultra vires the Minister's regulatory authority as set out in section 5(1) of the PPPFA.

The court held that the legislative scheme created by the PPPFA allocated points to bidders based on "specific goals", ${ }^{2}$ as contemplated in section 2 of the Act. Regulation

\footnotetext{
${ }^{1}$ Afribusiness NPC v Minister of Finance 2021 (1) SA 325 (SCA).

2 For a discussion on "specific goals" see Bolton 2007: 280-282.
} 
4 , on the other hand, adopted a different approach by conferring a discretion on organs of state to impose certain prequalification criteria as a condition of tender, in order to advance "designated groups". Not only was this contrary to section 2 of the PPPFA, but the Minister's failure to provide organs of state with a framework for the application of prequalification criteria made the process susceptible to abuse. ${ }^{3}$ The court held that the Minister's powers to make regulations were not unconstrained as he could only make regulations "regarding any matter that may be necessary or expedient to prescribe in order to achieve the objects of the Act". ${ }^{4}$

The ruling of the SCA was not entirely unexpected, for it is difficult to reconcile the concept of prequalification based on designated groups as described in regulation 4 with the preference-point system created by the PPPFA itself. ${ }^{5}$ In this respect, the ruling is reminiscent of the earlier case of Sizabonke Civils CC t/a Pilcon Projects v Zululand District Municipality in which the high court declared regulation 8 of the 2001 PPPFA regulations to be ultra vires. ${ }^{6} \mathrm{Had}$ the judgment of the SCA stopped at the ultra vires issue it would perhaps have been less contentious. However, the court went further and opined that the prequalification criteria do not meet the objectives set out in section 217(1) of the Constitution. We critique this view, as well as other aspects of the judgment which are seen as problematic.

\section{Commentary}

Three main areas are discussed below. First, the importance of reviewing the PPPFA regulations as a whole and not only the impugned regulations. Secondly, the finding by the SCA that prequalification criteria do not meet the objectives of section 217(1) of the Constitution and lastly the absence of an interim regime, pending the corrective action.

\footnotetext{
${ }^{3}$ Afribusiness para 38.

${ }^{4}$ Afribusiness para 37.

${ }^{5}$ The appellant argued (at para 25) that in terms of the PPPFA, persons disadvantaged on the basis of race, gender or disability could only be preferred based on a preference point system. See also Rainbow Civils CC v Minister of Transport and Public Works, Western Cape [2013] ZAWCHC 3 (6 February 2013) paras 97, 105.

${ }^{6}$ Sizabonke Civils CC t/a Pilcon Projects v Zululand District Municipality 2011 (4) SA 406 (KZP).
} 


\section{An opportunity to review the PPPFA regulations as a whole}

Although Afribusiness challenged only certain of the PPPFA regulations, ${ }^{7}$ namely, regulations $3(b),{ }^{8} 4,{ }^{9} 9^{10}$ and $10,{ }^{11}$ the SCA declared the regulations as a whole, invalid. To this end, the court held that due to the "interconnectedness" of the regulations, it would not have been appropriate to set aside regulation 4 only. ${ }^{12}$

It is difficult to see the "interconnectedness" of the regulations as a whole. For example, there is no obvious connection between the impugned regulations and regulation 5 which relates to functionality, regulation 13 which deals with cancellation of tenders, or regulation 14 which provides for remedies. There is no obvious reason why these regulations had to be struck down together with regulations 4 and 9 . It also seems strange that despite the court's finding that there was "nothing objectionable" about Regulation 10, it was declared invalid alongside the rest of the regulations! In contrast, the high court in Sizabonke Civils adopted a more "surgical" approach and declared only regulation 8 of the 2001 regulations invalid. The high court found that the remaining regulations read with the Act provided an adequate and workable framework for the evaluation of tenders. ${ }^{13}$

But these reservations aside, there is merit in asking the Minister to "return to the drawing board" in order to reconsider the regulations holistically. The problems with the PPPFA regulations are not confined to regulations $3(b), 4$, and 9 , since at least three other regulations require reconsideration, namely, Regulations 6, 7 and 8 . Regulations 6 and 7 can be dealt with together, as they prescribe a price/preference

\footnotetext{
${ }^{7}$ Afribusiness para 19.

${ }^{8}$ Regulation $3(b)$ requires organs of state to determine whether prequalification criteria are applicable to tenders, as envisaged in regulation 4.

${ }^{9}$ Regulation 4 deals with prequalification criteria that organs of state may apply to advance designated groups in public tendering. For the sake of brevity, these prequalification criteria will not be quoted verbatim, but it suffices to say that they include minimum B-BBEE levels, EME or QSE status and subcontracting a minimum of $30 \%$ to various designated groups.

${ }_{10}$ Regulation 9 deals with mandatory subcontracting and states that if feasible to subcontract for contracts above R30 million, organs of state must include a tendering condition that the successful tenderer must subcontract a minimum of $30 \%$ of contract value to various designated groups.

${ }^{11}$ Regulation 10 deals with the criteria for breaking a deadlock in scoring. Reg 10(1) states that if two or more bidders score an equal number of points, the contract must be awarded to the tenderer that scored the highest points for B-BBEE.

12 Afribusiness para 46.

13 Sizabonke Civils para 31.
} 
point system based on the value of the tender. ${ }^{14}$ The problem with regulations 6 and 7 is that the 20 or 10 preference points provided for are based entirely on a bidder's Broad-Based Black Economic Empowerment (B-BBEE) status level of contributor, as reflected on the bidder's B-BBEE scorecard. In contrast, the Act itself prescribes that the 20 or 10 points should be allocated to a broader set of "specific goals", not only to B-BBEE. Specific goals "may include" contracting with persons historically disadvantaged by unfair discrimination on the basis of race, gender or disability; or implementing the goals of the Reconstruction and Development Programme (RDP). The latter may include goals such as job creation, use of local labour or enterprises based in a particular locality. ${ }^{15}$ Significantly, the term "may include" suggests that the list of categories for which preference points may be given is not a closed list. Preference points may also be given to other important socio-economic objectives not specifically listed in the PPPFA, including objectives such as green procurement and the advancement of human rights in public procurement. The point is that there are design flaws in regulations 6 and 7 in that they incorrectly reduce the concept of "specific goals" to the B-BBEE scorecard. As such, these regulations are misaligned to the Act. ${ }^{16}$

Similarly, the manner in which regulation 8 deals with local production and content could be susceptible to challenge. Regulation 8 does not apply a preference point system, but stipulates minimum thresholds that have to be met in respect of "designated sectors". Arguably, local production and content is closely allied to the goal of local economic development envisaged in the RDP, and therefore ought to be dealt with through a preference point system and not by way of a minimum threshold. ${ }^{17}$

\footnotetext{
${ }^{14}$ Regulations 6 prescribes that for all tenders above R30 000,00 and up to R50 million, 80 points are allocated to price and 20 to preference. Regulation 7 prescribes that for tenders above R50 million, 90 points are allocated to price and 10 to preference.

${ }^{15}$ See for example, the approach followed in reg 17 of PPPFA regulations, 2001. It is somewhat ironic that although the RDP is no longer regarded as government's "flagship" policy, it has not been removed from the PPPFA, and as such the courts must give effect to it.

${ }^{16}$ Ironically, the 2011 PPPFA regulations were reviewed precisely for the reason that they restricted the framework for preferential procurement to B-BBEE credentials to the exclusion of other goals identified in the PPPFA. See para 3 of the judgment.

17 See reg 17 of the PPPFA regulations, 2001. To the best of our knowledge, the legality of regulation 8 has not been tested by the courts. See Powertech Transformers (Pty) Ltd v City of Tshwane Metropolitan Municipality and Others (44499/2017) [2018] ZAGPPHC 772 (20 March 2018); Continental Power Supplies (Pty) Ltd v Minister of Trade and Industry case no 89256/2018 (ZAGPPHC) (20 July 2020).
} 
A similar criticism could be directed at the manner in which the objectives of the National Industrial Participation Programme (NIPP) are currently incorporated into public-tender processes. ${ }^{18}$ Although not specifically dealt with in the PPPFA regulations, public-sector contracts with an imported content in excess of USD 10 million, attract a "NIPP obligation". Successful bidders are required to discharge their NIPP obligations through initiatives such as investment, sub-contracting, the formation of joint ventures, licensee production, export promotion and research and development. During the tender process, bidders are required to submit a returnable document (SBD 5) in terms of which they commit to the NIPP obligation upon award of business, but the problem is that no preference points are assigned to NIPP. ${ }^{19}$ Like local content and production, NIPP is designed to promote socio-economic objectives which are closely aligned to the objectives of the RDP. Arguably, NIPP ought to be dealt with as a "specific goal" for which preference points should be allocated. The incorporation of a "NIPP obligation" in the contract with the successful bidder, but without the allocation of preference points during the bidding process, seems at odds with the legislative scheme created by the PPPFA.

The absence of a proper regulatory framework for the incorporation of NIPP (and other policy objectives) in tender processes, places organs of state in an invidious position. Organs of state are not at liberty to ignore government policies and must give effect to them, ${ }^{20}$ but in doing so they could find themselves in breach of the PPPFA. In CTP $v$ Director-General Department of Basic Education, the SCA accepted that "[organs of state] can only deviate from [government policies] if there is a reasonable basis for such deviation in which case that basis should be clearly articulated". ${ }^{21}$ Possibly, the legal risk arising from the misalignment between NIPP and the preference-point system envisaged in the PPPFA could be regarded as a "reasonable basis" for organs of state not to implement NIPP, in the absence of a proper regulatory framework aligned to the PPPFA. The revision of the PPPFA will afford the Minister an opportunity

18 The National Industrial Participation Revised Guidelines, 2013 can be found on http://www.thedtic.gov.za/wp-content/uploads/Nip Guidelines2013.pdf.

${ }^{19}$ A copy of SBD 5 can be found on the National Treasury website http://ocpo.treasury.gov.za.

${ }^{20}$ CTP Ltd $v$ The Director-General Department of Basic Education [2018] ZASCA 156 (20 November 2018) para 30.

21 CTP para 30. 
to implement all socio-economic objectives envisaged in section 2(1)(d) of the PPPFA, including NIPP, through a proper preference-point system.

Regulation 5 also deals with functionality by way of a minimum threshold, and not by way of preference points. But in our view, this is less unproblematic. Functionality relates to "the ability of a tenderer to provide goods or services in accordance with specifications as set out in the tender documents". 22 This usually encompasses quality and technical criteria and thus falls outside the scope of the preference-point system envisaged in section 2 of the PPPFA.

In summary, it would be prudent to use the opportunity afforded by the SCA's ruling to reconsider the PPPFA regulations as a whole, not only the impugned regulations. In our view, it is erroneous to limit the concept of "specific goals" to the B-BBEE scorecard. Preference points must be allocated to two distinct categories, namely, contracting with persons who were historically disadvantaged by race, gender or disability and promoting the goals of the RDP. The goals of the RDP should not be regarded as coextensive with the B-BBEE Codes, as the former covers a wider area of objectives not specifically addressed in the Codes. Furthermore, preference points may also be given to the furtherance of socio-economic goals that are not specifically listed in the PPPFA.

\section{Prequalification and section 217(1) of the Constitution}

Perhaps the most contentious aspect of the SCA's ruling is the finding that the discretionary prequalification criteria listed in Regulation 4 constitute a "deviation" from section 217(1) of the Constitution. ${ }^{23}$ The court held that "any prequalification requirement which is sought to be imposed must have as its objective the advancement of the requirements of section 217(1) of the Constitution". ${ }^{24}$ The reference to prequalification criteria as a "deviation" suggests that they are a departure

\footnotetext{
22 Section 1 of the PPPFA regulations, 2017.

${ }^{23}$ Afribusiness para 38. Some might regard the SCA's comments on this aspect as an obiter remark.

24 Afribusiness para 38.
} 
from an accepted norm or standard - in other words, they should be viewed as a discrepancy or anomaly. ${ }^{25}$

Before dealing with this aspect we point out, in parenthesis, that the judgment hardly mentions anything about Regulation 9. As already stated, Regulation 9 deals with subcontracting and makes it mandatory for organs of state to advertise tenders above R30 million with a tendering condition that the successful tenderer must subcontract $30 \%$ of contract value to designated groups. Despite the fact that Regulations 4 and 9 overlap to some extent (in that they identify the same categories of designated groups), the two regulations operate differently. Regulation 9 does not operate as a prequalification in the same way as Regulation 4. Regulation 9 imposes a subcontracting obligation on the successful bidder, whereas regulation 4 operates as a filter to allow only those bidders which meet the prequalification criteria to participate in the tender. It is not clear why the court did not address the problems associated with regulation 9 explicitly, but presumably the court's concerns regarding regulation 4 were also applicable to regulation 9.

The court's reasoning that Regulation 4 deviated from section 217(1) was dealt with in a rather cursory fashion. The court did not explain clearly why the prequalification criteria amounted to a deviation, or which of the five principles listed in section 217(1) had been deviated from. ${ }^{26}$ It would have been illuminating had the court provided more detailed reasoning for its finding on this important issue. However, the court's reliance on its earlier ruling in Airports Company of South Africa $v$ Imperial provides some insight into its reasoning. ${ }^{27}$ In ACSA, the SCA described the remedial measures contemplated under sections 217(2) and (3) of the Constitution as an "exception" to the general rule outlined in section 217(1) that all public procurement had to be in accordance with a system that is fair, equitable, transparent, competitive and cost-

${ }^{25}$ Reg 4 applies race, gender and youth as prequalification criteria in an indirect manner. Tenderers satisfy the prequalification criteria if they agree to subcontract $30 \%$ of the contract value to designated groups, based on race, gender, youth etc. But in terms of Reg 4, race, gender and youth cannot operate as prequalification criteria in their own right.

${ }^{26}$ Afribusiness para 38. Section $217(1)$ suggests that all 5 principles operate together to form a "system" of procurement. If one principle is not observed, the system as a whole could be compromised. Bolton 2007: 55 - 56. It would have been beneficial had the court explained which of the 5 principles had not been observed.

27 Airports Company South Africa v Imperial Group Ltd 2020 (4) SA 17 (SCA). 
effective. ${ }^{28}$ The court in ACSA reasoned that had sections $217(2)$ and (3) not been inserted in the Constitution, the use of public procurement as an instrument of transformation could have been stultified by "by appeals to the guarantee of equality and non-discrimination in section 9 of the Constitution". ${ }^{29}$ But the court made it clear that the freedom conferred on organs of state to implement preferential procurement policies was circumscribed by section $217(3)$ which states that national legislation should prescribe a framework within which preferential procurement policies could be applied. As the court saw it, organs of state could only "escape" from the principles outlined in section 217(1), if they were able to bring their preferential procurement policies within sections (217(2) and (3).

It is trite that in order to survive judicial scrutiny, preferential procurement measures must be brought within the ambit of the legislation contemplated in sections217(2) and (3), namely, the PPPFA and the B-BBEE Act. But there are at least three problems with the blanket statement that preferential procurement measures constitute a "deviation" from section 217(1) principles. First, the wording of section 217, read as a whole, suggests otherwise. Section 217(2) states expressly that subsection (1) "does not prevent" organs of state from applying remedial measures in the context of public procurement. The term "does not prevent" suggests that there is nothing in the wording of section 217(1) which should be viewed as an obstacle or hindrance to the remedial measures contemplated in section 217(2) and (3). Indeed, one of the five principles outlined in section $217(1)$ is the pursuit of equity. The concept of equity has been interpreted to mean social equity - it refers to the use of the state's contracting power as an empowerment tool. ${ }^{30}$ In this respect, the use of prequalification criteria to advance the goals of social equity can hardly be said to constitute a deviation from the principle of equity in section $217(1)$.

Secondly, an oppositional reading of section 217(1) and subsections (2) and (3) does not accord with our jurisprudence on substantive equality, as expounded by the Constitutional Court. It is instructive to see how the Constitutional Court has interpreted section 9 of the Constitution (the right to equality), since this has a bearing

\footnotetext{
${ }^{28}$ ACSA para 64.

29 ACSA para 64.

30 Bolton 2007:49 - 53.
} 
on the issue discussed here. Although section 9 is not worded in exactly the same manner as section 217, there are important similarities. Both sections protect the right to fair and equal treatment before the law (subsections 9(1) and 217(1)), whilst simultaneously permitting the use of remedial measures aimed at overcoming the disadvantages imposed by unfair discrimination (subsections 9(2) and 217(2)). In Minister of Finance $v$ Van Heerden, the Constitutional Court emphasized that the concepts of equal protection and remedial justice as outlined in section 9 , require a harmonious reading. ${ }^{31}$ This is because restitutionary measures "are not in themselves a deviation from, or invasive of, the right to equality", but rather a substantive and composite part of equal protection. ${ }^{32}$ In fact, "a disjunctive or oppositional reading of the two subsections would frustrate the foundational equality objective of the Constitution and its broader social justice imperatives". ${ }^{33}$ The view that remedial measures such as prequalification criteria constitute a deviation from section 217(1), seems to be based on the type of oppositional reasoning which the Constitutional Court sought to avoid.

In this regard, our Constitution differs significantly from other constitutions, most notably the US Constitution, which treats remedial measures based on race or gender as "suspect" and thus subjected to strict judicial scrutiny. ${ }^{34}$ The court in Van Heerden made it clear that if restitutionary measures based on factors such as race and gender pass muster under section $9(2)$, they cannot be regarded as presumptively unfair under section $9(3) .{ }^{35}$

Thirdly, the notion that prequalification criteria constitute a "deviation" from section 217(1) has significant implications for how similar measures envisaged in the new Procurement Bill are perceived. The Bill makes provision for various measures to advance socio-economic objectives, including the use of "set asides". ${ }^{36}$ The concept of "set asides" usually means that certain contracts are reserved for designated groups or that a certain percentage of the works or services ought to be subcontracted to

\footnotetext{
${ }^{31}$ Minister of Finance $v$ Van Heerden 2004(11) BCLR 1125 (CC) para 28.

32 Van Heerden para 30, 32.

33 Van Heerden para 30.

34 Van Heerden paras 29, 147 - 148.

35 Van Heerden para 33.

${ }^{36}$ Clause 26 of the Bill.
} 
designated groups. In other words, bidders must meet certain prequalification criteria (including, but not limited to race and gender) in order to participate in a bidding process. The charge that prequalification criteria constitute a deviation from section $217(1)$ calls into question the use of such measures in the Bill as well. ${ }^{37}$

The concept of "set asides", 38 though by no means unique to South Africa ${ }^{39}$, has generated considerable debate within the South African public procurement arena. At some stage, National Treasury prohibited the practice of set asides altogether. 40 Academic authors have also expressed reservations about the practice. ${ }^{41}$ The main concerns appear to be with the exclusionary effect set asides have on the market, coupled with the adverse impact that effect is said to have on cost-effectiveness and competitiveness. ${ }^{42}$ In our view, there is nothing constitutionally suspect about the use of remedial measures such as prequalification criteria or set asides per se. Much depends on the rationale for the use of set asides as well as the manner in which such measures are designed and implemented. For instance, a set aside aimed at advancing women-owned micro enterprises based in rural areas is more likely to survive judicial scrutiny if it can be demonstrated that the measure is informed by a proper market analysis, is limited in scope and duration, is directed at a specific class of beneficiaries, that the impact on the non-favoured class is not disproportionate and that the principles of competitiveness and cost effectiveness are not undermined to a material degree. This underscores the need for proper guidelines to be given to organs of state when applying prequalification or set aside criteria, as the SCA in Afribusiness alluded to.

The watchwords are rationality, proportionality and reasonableness - for not everything done in the name of "transformation" will necessarily pass constitutional

\footnotetext{
37 Clause 26(1) requires the Minister of Finance to prescribe a framework for preferential procurement. However, this is probably in breach of section 217(3) which requires Parliament to prescribe such a framework, and not the Minister. Hopefully, this will be corrected in subsequent drafts of the Bill.

${ }^{38}$ The term "set asides" refers to a policy or practice of reserving a certain percentage of procurement spend for designated (targeted) groups - usually based on race or gender.

39 Cravero 2017:174.

${ }^{40}$ National Treasury Practice Note Number SCM 2 of 2006. To the best of the authors' knowledge, this Practice Note has not been revoked.

41 Bolton 2010:113 - 114 .

42 Bolton 2010:113 - 114 expressed the view that the allocation of preference is more aligned to section $217(1)$ than the use of set asides.
} 
muster. Measures which are poorly designed, haphazardly implemented, display "naked preference" or which contravene the law will invariably be struck down. ${ }^{43}$ To pass constitutional muster, remedial measures must at least satisfy the test set out by the Constitutional Court in Van Heerden (the so-called Van Heerden test). ${ }^{44}$ The law on remedial equality calls for a credible process of remediation for past exclusion one which is designed and implemented within the discipline of the Constitution. ${ }^{45}$

We accept that poorly-designed prequalification or set aside measures may be struck down as unconstitutional. However, the difficulty lies with the blanket statement that prequalification measures offend against section 217(1) of the Constitution. It is our contention that properly designed remedial measures do not amount to a deviation from the principles of fairness and equal treatment nor do they amount to "reverse discrimination". ${ }^{46}$ They are not intended to impose punishment or retribution on the previously-advantaged group, but rather to promote the achievement of meaningful equality in South Africa. For that reason "affirmative measures should be welcomed rather than treated with suspicion." 47 The real problem with the prequalification criteria outlined in Regulation 4 is not that they deviate from section 217(1), but rather that they were not implemented within the legislative scheme envisaged in section 217(3).

\section{Does the B-BBEE Act provide an alternative basis for prequalification?}

Since Afribusiness, there has been some public discussion on whether the BroadBased Black Economic Empowerment Act, ${ }^{48}$ its regulations and codes provide an alternative basis for setting prequalification criteria based on race and gender in public tenders. ${ }^{49}$ In our view, the B-BBEE legal regime, as currently formulated, does not

\footnotetext{
${ }^{43}$ See for instance Minister of Justice and Constitutional Development $v$ South African Restructuring and Insolvency Practitioners Association 2018 (5) SA 349 (CC); ACSA; Rainbow Civils.

${ }^{44}$ Van Heerden paras 38 - 44: In essence the Van Heerden test requires that remedial measures satisfy three requirements: They should (a) be designed to protect or advance a disadvantaged class; (b) be reasonably capable and of achieving their objective and (c) promote the achievement of equality. See also South African Police Service v Solidarity obo Barnard 2014 (10) BCLR 1195 (CC) paras 36, 142 149; 160; SARIPA paras $38-48$.

45 Van Heerden para 25.

46 Van Heerden para 30.

${ }^{47}$ Barnard para 137.

48 Act 53 of 2003.

${ }^{49}$ See for example the media statement issued by Department of Trade Industry and Competition dated 4 November 2020 "The Supreme Court of Appeal Ruling on the Validity of the PPPFA Regulations of 2017 Has No Effect on the B-BBEE Act and its Requirements", last accessed from http://www.thedtic.gov.za on 13 November 2020.
} 
permit organs of state to set prequalification criteria in public tenders without prior ministerial approval, as envisaged in section 9(6) of the B-BBEE Act.

In terms of section 9(1)(b), the Minister may issue codes of good practice on B-BBEE which may include prequalification criteria for preferential purposes for procurement and other economic activities. In terms of section 10(1)(a) and (b) such codes must be applied in determining qualification criteria for various economic activities and when developing and implementing a preferential procurement policy. The Minister has issued the Generic Code of Good Practice (CGP) as well as ten sector-specific codes. However, these codes do not set out any "qualification criteria for preferential purposes for procurement and other economic activities" as envisaged in section 9(1)(b). At best, the codes set out sub-minimum requirements for certain priority elements (ownership, skills development and enterprise and supplier development) which must be met for a measured entity to earn points. But these priority elements do not permit organs of state, without more, to stipulate prequalification criteria (such as black ownership) in public tenders.

But the B-BBEE Act provides a solution. It makes provision for mechanisms that must be followed by organs of state wishing to impose empowerment criteria which are different to those set out in the B-BBEE codes. Section 9(6) provides that an organ of state wishing to specify qualification criteria for procurement which exceed those set in the codes must request the Minister's permission to do so. Furthermore, section 10(2)(a) allows the Minister to exempt an organ of state from applying B-BBEE prescripts or allowing a deviation therefrom if there are "objectively verifiable facts or circumstances" which justify such exemption or deviation. What is clear is that an organ of state cannot impose its own empowerment criteria in the absence of ministerial consent. Section 10 (3) states explicitly that an enterprise "may only" be measured for compliance with B-BBEE requirements in accordance with the applicable code, unless the Minister grants permission in terms of section 9(6) to set different qualification criteria. 
This point was made clear in the ACSA case. ${ }^{50}$ In ACSA, an organ of state argued that the B-BBEE Act did not preclude it from setting $51 \%$ black ownership as a prequalification criterion in a tender. The SCA disagreed. The court explained that the B-BBEE regime prescribes a formula for the allocation of points when determining $B-$ BBEE compliance. ${ }^{51}$ Organs of state which are not content with this point-scoring mechanism, have recourse to the Minister in terms of section 9(6) to seek permission to exceed the standards set in the codes. ${ }^{52}$ But it is not open to an organ of state to "design its own custom-made set of prequalification criteria" without ministerial consent. ${ }^{53}$ Not only would such an approach undermine the uniformity which the BBBEE regulatory regime has sought to achieve, but it would permit organs of state to arrogate to themselves a power reserved for the Minister. ${ }^{54}$

The upshot is that prior ministerial consent is an indispensable requirement for setting prequalification criteria such as $51 \%$ black ownership or other elements of the scorecard. The regulations prescribe various formalities, procedures and templates which must be followed when seeking ministerial approval. ${ }^{55}$ These formalities must be adhered to strictly, as failure to observe prescribed formalities on the part of either the Minister or the requesting public body may render a decision by the Minister to grant approval open to legal challenge.

\footnotetext{
${ }^{50}$ ACSA.

${ }^{51}$ ACSA para 40.

52 ACSA para 35.

${ }^{53}$ ACSA para 37.

${ }^{54}$ ACSA para 38. See also Rainbow Civils paras $105-106$.

${ }^{55}$ Regulation 19 of the B-BBEE regulations 2016, prescribes the process to be followed when seeking permission to exceed qualification criteria in terms of s 9(6) of the B-BBEE Act and reg 20 prescribes the process to be followed when seeking exemption or deviation in terms of $s$ 10(2).
} 


\section{How should organs of state approach regulations 4 and 9 during the period of suspension?}

It is commonplace for courts, when suspending a declaration of invalidity, to put in place an interim regime pending the corrective action. ${ }^{56}$ Sometimes this involves a declaration by the court that the impugned provision should not be applied during the period of suspension, ${ }^{57}$ alternatively that it should be applied differently. ${ }^{58}$ The obvious benefit is that it removes uncertainty and doubt and guides the parties on how the impugned provisions should be applied during the interim period. Unfortunately, in Afribusiness, the court did not put an interim regime in place. The question that arises is how organs of state should apply the regulations during the twelve-month period of suspension.

As a matter of law, the regulations remain in force during the period of suspension. ${ }^{59}$ Thus, technically, the regulations as a whole could be applied as they stand. In fact, absent a proper regulatory framework it would be extremely difficult to administer public tender processes during the interim period. But there is a caveat. As stated by the Constitutional Court in S v Steyn, a suspension order is "intended to avert disorders or dislocation that may arise as a result of an immediate declaration of invalidity. [B] ut the mechanism by no means sanctions tolerance for that which has already been adjudged inconsistent with the Constitution. Even in the face of this Court's suspension of an order of validity, it is imperative that obligations imposed by the Constitution remain". ${ }^{60}$ Should an organ of state apply the impugned regulations $3(b), 4$ and 9 during the period of suspension, it may well be faced with a legal challenge.

\footnotetext{
56 See for instance Economic Freedom Fighters v Minister of Justice and Correctional Services 2021 (2) BCLR 118 (CC) para 78; AllPay Consolidated Investment Holdings v Chief Executive Officer, South African Social Security Agency 2014 (4) SA 179 (CC) paras 63, 78; Brummer v Minister for Social Development 2009 (6) SA 323 (CC) paras 74 - 76; S v Steyn 2001 (1) SA 1146 (CC) para 53; National Coalition of Gay and Lesbian Equality v Minister of Home Affairs 1999 (3) SA 173 (CC) 190 F-I; Executive Council Western Cape v Minister of Provincial Affairs 2000 (1) SA 661 (CC) para 139; First National Bank of South Africa Ltd $v$ Land and Agricultural Bank of South Africa; Sheard $v$ Land and Agricultural Bank of South Africa 2000 (3) SA 626 (CC) paras 18, 20; Sizabonke Civils. See also Currie \& De Waal 2013:194 - 195; Du Plessis 2013:120.

57 First National Bank of South Africa Ltd v Land and Agricultural Bank of South Africa; Sheard v Land and Agricultural Bank of South Africa para 18.

${ }^{58}$ Brummer para 76.

59 Currie \& De Waal 2013:192.

$60 \mathrm{~S} v$ Steyn para 45.
} 
In our view, the safer approach would be to avoid the application of the impugned regulations during the period of suspension. Regulation 4 is discretionary in nature and thus organs of state are entitled to exercise their discretion to not apply the regulation during the suspension period. Regulation 9 , on the other hand, is worded in a peremptory fashion. It compels organs of state to apply subcontracting to advance designated groups for all contracts above R30m. However, the obligation is prefaced by the words "if feasible". The regulations do not prescribe how the feasibility of subcontracting must be assessed, ${ }^{61}$ and there is no reason to confine an assessment "feasibility" to operational or technical feasibility only. Organs of state may thus determine that it is not feasible to implement regulation 9, in view of the legal risk which prevails. ${ }^{62}$ Presumably National Treasury will issue some sort of guidance note or directive on the matter in due course, ${ }^{63}$ but this itself is unsatisfactory, as it should not be left to government functionaries to fill a void left in a court judgment.

\section{CONCLUSION}

The finding by the SCA that regulations $3(b), 4$ and 9 are ultra vires the PPPFA, provides an opportunity for the Minister to revisit the PPPFA regulations as a whole. We have argued that the focus should not be on the impugned regulations only, but that other regulations need to be revised as well. Regulations 5 and 6 , in particular, need to be revised insofar as they erroneously confine the concept of preference points for "specific goals" to a bidder's B-BBEE status. "Specific goals" as set out in the PPPFA is more encompassing than B-BBEE. Likewise, the approach to "local production and content" must be reviewed. The regulations should probably assign preference points to local production and content as a "specific goal", as opposed to the current threshold-based approach. The same applies with respect to the application of NIPP in public tenders.

\footnotetext{
61 However, para 14 of the PPPFA Implementation Guide (March 2020) provides some guidance on this aspect.

62 We acknowledge this contribution made by participants during an online seminar held by the Special Interest Group of the Administrative Justice Association of South Africa (AdJASA) on 12 November 2020 to discuss the Afribusiness decision.

63 In Sizabonke Civils, the provincial treasury issued a circular to address the conflict between the PPPFA and the 2001 regulations.
} 
We are not particularly concerned about the finding that regulation 4 is ultra vires the PPPFA. Our main concern lies with the finding that prequalification criteria of the kind outlined in regulation 4 conflict with the principles outlined in section 217(1) of the Constitution. We submit that prequalification criteria or "set asides", designed and implemented in a constitutionally-responsible manner, do not offend against the principle of fair and equal treatment of bidders.

The available options to remedy the defects in the regulations are limited. The Minister will probably be required to repeal the use of prequalification criteria and instead apply a preference-point system based on a wide range of "specific goals". However, this has far-reaching implications for the use of public procurement as a tool of socioeconomic transformation, as the current preference-point system is an inadequate and blunt tool of transformation. All this points to the fact that the PPPFA has run its course and should be replaced as a matter of urgency. For this reason, the passage of the Procurement Bill must be expedited. 


\section{BIBLIOGRAPHY}

\section{Literature}

Bolton, P. 2007. The Law of Government Procurement in South Africa. Durban: Lexis Nexis.

Currie, I \& De Waal, J. 2013 The Bill of Rights Handbook 6 ed. Claremont: Juta.

Du Plessis, Max (et al). 2013. Constitutional Litigation. Claremont: Juta.

Bolton, P. 2006. Government Procurement as a Policy tool in South Africa. Journal of Public Procurement 6:193.

Bolton, P. 2010. The regulation of preferential procurement in state-owned enterprises. TSAR 101.

Cravero, C. 2017. Socially Responsible Public Procurement and Set-Asides: A Comparative Analysis of US, Canada and the EU. Artic Review on Law and Politics 8:174.

Media statement issued by Department of Trade Industry and Competition dated 4 November 2020 "The Supreme Court of Appeal Ruling on the Validity of the PPPFA Regulations of 2017 Has No Effect on the B-BBEE Act and its Requirements", last accessed from http://www.thedtic.gov.za on 13 November 2020.

\section{Case Law}

Afribusiness NPC v Minister of Finance [2020] ZASCA 140 (2 November 2020)

Airports Company South Africa v Imperial Group Ltd 2020 (4) SA 17 (SCA)

AllPay Consolidated Investment Holdings v Chief Executive Officer, South African Social Security Agency 2014 (4) SA 179 (CC)

Brummer v Minister for Social Development 2009 (6) SA 323 (CC)

Continental Power Supplies (Pty) Ltd $v$ Minister of Trade and Industry case no 89256/2018 (ZAGPPHC)(20 July 2020) 
CTP Ltd $v$ The Director-General Department of Basic Education [2018] ZASCA 156 (20 November 2018)

Economic Freedom Fighters v Minister of Justice and Correctional Services 2021 (2) BCLR 118 (CC)

Executive Council Western Cape v Minister of Provincial Affairs 2000 (1) SA 661 (CC)

First National Bank of South Africa Ltd v Land and Agricultural Bank of South Africa; Sheard v Land and Agricultural Bank of South Africa 2000 (3) SA 626 (CC)

Minister of Finance $v$ Van Heerden 2004 (11) BCLR 1125 (CC)

Minister of Justice and Constitutional Development $v$ South African Restructuring and Insolvency Practitioners Association 2018 (5) SA 349 (CC)

National Coalition of Gay and Lesbian Equality v Minister of Home Affairs 1999 (3) SA $173(\mathrm{CC})$

Powertech Transformers (Pty) Ltd v City of Tshwane Metropolitan Municipality and Others [2018] ZAGPPHC 772 (20 March 2018)

Rainbow Civils CC v Minister of Transport and Public Works, Western Cape [2013] ZAWCHC 3 (6 February 2013)

Sizabonke Civils CC ta Pilcon Projects v Zululand District Municipality 2011 (4) SA 406 (KZP)

S v Steyn 2001 (1) SA 1146 (CC)

South African Police Service v Solidarity obo Barnard 2014 (10) BCLR 1195 (CC)

\section{Legislation}

Broad-Based Black Economic Empowerment Act 53 of 2003

B-BBEE Regulations, 2016

B-BBEE Generic Codes of Good Practice, 2013 
Preferential Procurement Policy Framework Act 5 of 2000

Preferential Procurement Regulations, 2001

Preferential Procurement Regulations, 2017

\section{Policies}

The National Industrial Participation Revised Guidelines, 2013, last accessed on http://www.thedtic.gov.za/wp-content/uploads/Nip Guidelines2013.pdf $\quad$ on 4 December 2020. 